\title{
GROUND-DWELLING ANT FAUNA OF SITES WITH HIGH LEVELS OF COPPER
}

\author{
DIEHL, E., SANHUDO, C. E. D. and DIEHL-FLEIG, Ed. \\ Programa de Pós-Graduação em Biologia: Diversidade e Manejo de Vida Silvestre, Laboratório de Genética \\ de Insetos Sociais, Universidade do Vale do Rio dos Sinos, UNISINOS, C.P. 275, \\ CEP 93001-970, São Leopoldo, RS, Brazil \\ Correspondence to: Dra. Elena Diehl, Laboratório de Genética de Insetos Sociais, UNISINOS, \\ C.P. 275, CEP 93001-970, São Leopoldo, RS, Brazil, e-mail: ediehl@bios.unisinos.br \\ Received October 1, 2002 - Accepted February 17, 2003 - Distributed February 29, 2004
}

\begin{abstract}
Richness and diversity of ant species are related to environmental factors such as vegetation, soil, presence of heavy metals, and insecticides, which allow the use of the assemblage members as terrestrial indicators of environmental conservation status. This study presents the results of ground ants surveyed in Minas do Camaquã in the municipality of Caçapava do Sul (Camaquã Basin), State of Rio Grande do Sul. Collections were performed in four sites, with high levels of copper in the soil, three of which - a mine, a liquid reject, and a solid reject -, had sparse or no plant cover, and one site where Pinus has been used for rehabilitation. Parque das Guaritas was the control site, since it presented normal levels of copper and a dense savanna cover. For each site, three transect lines extending $100 \mathrm{~m}$ were draw, and at each $10 \mathrm{~m}$ sardine baits were distributed; after two hours the ants present were collected. Hand collections in all five sites were performed during one hour (capture effort). A total of 51 species belonging to 17 genera were collected. The control site was the richest in ant species $(r=45)$. Sites with high level of copper and poor plant cover presented the lowest richness: mine $(r=14)$, solid reject $(r=15)$, and liquid reject $(r=16)$. In contrast, the site planted with Pinus presented an increment in richness $(r=24)$ of ground-dwelling ants, suggesting a reahabilitation process.
\end{abstract}

Key words: Insecta, Formicidae, copper mines, biodiversity, epigaeic ants.

\section{RESUMO}

\section{Mirmecofauna de solo em áreas com altos níveis de cobre}

A riqueza e a diversidade de formigas estão relacionadas a fatores como vegetação, solo, presença de metais pesados e inseticidas, o que permite usar membros das comunidades como indicadores terrestres do estado de conservação ambiental. Neste trabalho são apresentados dados sobre a fauna de formigas nas Minas do Camaquã, Caçapava do Sul (Bacia do Camaquã), Rio Grande do Sul. As coletas foram realizadas em quatro áreas com altos teores de cobre no solo, dentre as quais três - minas, rejeito líquido e rejeito sólido - apresentaram pouca ou nenhuma vegetação e uma apresentou área de recuperação com Pinus. A área controle foi o Parque das Guaritas, por apresentar teores normais de cobre e densa vegetação típica de savana. Foram traçados três transectos de $100 \mathrm{~m}$ por área e, a cada $10 \mathrm{~m}$, foi colocada uma isca de sardinha. As iscas ficaram expostas por duas horas e, após esse tempo, as formigas presentes foram coletadas. Também foram realizadas coletas manuais, durante uma hora (esforço de captura), nas cinco áreas. Ao todo foram coletadas 51 espécies, distribuídas em 17 gêneros. A área controle apresentou a maior riqueza de espécies $(r=45)$, enquanto as áreas com altos teores de cobre e pouca vegetação apresentaram as menores riquezas: mina $(r=14)$, rejeito sólido $(\mathrm{r}=15)$ e rejeito líquido $(\mathrm{r}=16)$. A área plantada com Pinus apresentou aumento na riqueza $(\mathrm{r}=24)$ de espécies de formigas de solo, sugerindo sua recuperação.

Palavras-chave: Insecta, Formicidae, minas de cobre, biodiversidade, formigas epigéicas. 


\section{INTRODUCTION}

Local abiotic processes, interaction among species, and chance tend to affect biodiversity. Richness of local species can be limited by resource (food and nesting sites), by physical factors (temperature and humidity), and soil conditions (Ricklefs \& Schluter, 1993; Andersen, 2000). At the same time, interactions among populations regulate the access by others to the habitat, thus regulating the use of resources that can influence local diversity (Kaspari, 2000).

Works concerning particularly invertebrate fauna have been used to gauge the effects of agriculture and forestry management activities as well as the success of rehabilitation programs in mine areas (Andersen, 1990, 1993; Majer, 1983, 1992; Majer \& Nichols, 1998; Silva \& Brandão, 1999). Ants form a group of insects which is numerically abundant and species rich, generally found in high trophic levels and, frequently, in specialized niches (Hölldobler \& Wilson, 1990). It has been suggested that local richness and diversity of ants are related to plant richness and diversity, and could also provide an indication of invertebrate fauna present as well as soil conditions (Majer et al., 1984; Majer, 1992; Majer \& Koch, 1992). Ground-dwelling ants represent a group that can easily be sampled and their communities are good candidates for use in biodiversity inventories and monitoring programs owing to their relative stability, moderate diversity, and sensitivity to climate and microclimate conditions (Alonso \& Agosti, 2000).

In Rio Grande do Sul, southern Brazil, there are copper mines in the sub-basin of João Dias belonging to Camaquã Basin. Some kilometers away from the mines sites are found, such as Parque das Guaritas, with normal copper levels in the soil, and presenting a varied profile with many rocks, caves, and ruins, intermingling with a rich vegetation. This area is thus considered an important site for preservation.

The copper mines were largely exploited in the last hundred years, changing the regional landscape as well as causing several environmental disturbances. During copper extraction, a large amount of solid reject was produced (stones without economically important mineral ores), which significantly disturbed the landscape. To extract copper mineral, a series of breaking processes is necessary, in addition to hidrocyclones and floating and decanting processes. The last steps, aimed at purifying the product, produce a great sterile volume, composed of fine material which was then deposited in the decanting sites (liquid reject).

Copper, when exceeding normal levels, is one of the most toxic trace elements to most organisms, including man (Esteves, 1988). Thus, several researches involving flora and fauna, including this work, of the copper mines in the sub-basin of João Dias, are aimed at the rehabilitation of disturbed areas, as well as the preservation of the Parque das Guaritas. This study surveyed the ant fauna and compared the community structure of the grounddwelling ants from the Parque das Guaritas (control site), the copper open mine, the two copper reject sites, and a rehabilitation site in Minas do Camaquã.

\section{MATERIAL AND METHODS}

This study was carried out from November 1997 to January 1999 in the Camaquã mines, located in the Municipality of Caçapava do Sul, in the João Dias sub-basin, belonging to the Camaquã Basin, State of Rio Grande do Sul. The sub-basin is located between the coordinates $30^{\circ} 47^{\prime} \mathrm{S}$ and $52^{\circ} 24^{\prime} \mathrm{W}$.

The sub-basin vegetation is savanna with a continuum of herbaceous strata; trees, grouped or not; and gallery forest. As quoted by Guadagnin $e t$ al. (2000), the region presents an important number of endemic plant species, even though the area is not yet very well studied.

According to the classification of Köppen, the local climate is mesothermal, moderate, with temperate periods, annual average temperature of $16.8^{\circ} \mathrm{C}$, and average relative humidity of $77 \%$. Rainfalls vary between $1,200 \mathrm{~mm}$ and $1,500 \mathrm{~mm}$, with maximum amounts of rainfall in January, April, and September (Hansen \& Fensterseifer, 2000; Ronchi et al., 2000).

The levels of copper in the soil of the João Dias sub-basin vary from $0 \mathrm{mg} / \mathrm{L}$ to $3 \mathrm{mg} / \mathrm{L}$, while in some sites of the bed of the João Dias stream, copper levels can be up to 500 times higher in relation to normal levels. Copper contamination is higher upstream of the reject dam (Ronchi et al., 2000).

The ant collections were made in four sites having high copper levels: the open mine, the solid and liquid reject areas, the rehabilitation area, and 
a site with normal copper concentration (control). The copper mine has no plant cover, while the solid reject site has rare and sparse herbs and shrubs. The vegetation around the liquid reject site is poor and scattered. The rehabilitation site is a solid reject area planted with the exotic tree Pinus elliotti (Pinaceae). The control area, Parque das Guaritas, $10 \mathrm{~km}$ distant from the copper mine, has a dense and diverse native herbaceous cover with many shrubs.

Two complementary sampling methods were utilized to survey the ant fauna: sardine baits and hand collections. For each site, three transects lines $100 \mathrm{~m}$ long were drawn, $150 \mathrm{~m}$ distant from each other. For each transect, at $10 \mathrm{~m}$ intervals sardine baits were distributed. The ants present in the baits after two hours were collected. Hand collections in each one of the five sites were performed during one hour (capture effort).

Ants were sorted into tribes, and generic names used are those in Hölldobler \& Wilson (1990). Specific keys were used for identification to species level. For morphospecies, the codes used were of the reference collection of the Social Insect Section of the Genetics Laboratory at UNISINOS, where a full voucher collection is housed.

For calculation of the species richness of each site, and similarity between sites, data were used from the sardine bait locations and hand collections. The community structure of the ground-dwelling ants was analyzed using only the data provided by the sardine baits. For analyzing community structure, Quantan software was used (Zar \& Brower, 1997).

\section{RESULTS AND DISCUSSION}

The epigaeic ants specie collected by both sampling methods in the five sites evaluated in the João Dias sub-basin are shown in Table 1. Of the 51 species collected, $88.2 \%$ were found in the control site. The sites with high copper levels presented the lowest number of ant species. Only Acromyrmex lundi, Conomyrma sp., Camponotus (Myrmaphaenus) sp., and Solenopsis invicta were common to all sites with high copper levels in the soil, and the control area, Parque das Guaritas. The two last species are very common in several ecosystems occurring in high frequency (E.D. pers. obs.) in Rio Grande do Sul. The fact that these species were found in all sites evaluated in the João Dias sub-basin suggests that they present an enormous adaptive plasticity, possibly having genic potential to exploit a great variety of environments, including highly disturbed ones. According to Alonso \& Agosti (2000), there are several ant species in all parts of the world that are well adapted to living in disturbed environments and are the first to colonize these sites.

Table 2 shows the three genera with highest species number in the five sites. The genera Camponotus and Pheidole are characterized by a great amount of species found in many different environments (Wilson, 1976), supporting the results. The species richness of these three genera increased as the level of copper in the soil decreased, as well as in the area revegetated with $P$. elliotti, suggesting its rehabilitation, as proposed by Majer et al. (1984), Majer (1992, 1996), Andersen (1993), and Majer \& Nichols (1998). It is interesting to note the high number (8) of Acromyrmex species present in Parque das Guaritas, corresponding to $61.5 \%$ of all species of this genus occurring in Rio Grande do Sul (Mayhé-Nunes \& Diehl-Fleig, 1994).

The results indicate a clear correlation between richness and diversity of the ground-dwelling ant fauna, and density and diversity of the plant cover, which is probably correlated with the copper level in the soil. Thus, the highest richness $(r=45)$ and diversity $(H=1.214)$ of ant species were found in Parque das Guaritas (Table 3). The rich plant cover of this area probably leads to a more favorable microclimate, providing microhabitats for ants and many other invertebrates.

The mine and the two other sites with high copper concentration, possibly due to the low plant cover, presented the lowest richness and diversity of ant species. The old solid reject site, now being rehabilitated with $P$. elliotti, presented a strong increment of richness $(\mathrm{r}=24)$ and diversity $(\mathrm{H}=$ 1.046) of ant species, even though both parameters are clearly inferior to those found for Parque das Guaritas $(\mathrm{r}=45 ; \mathrm{H}=1.214)$. In Australia, an increase in richness and diversity of ground-dwelling ants was reported as the mine areas of bauxite and uranium recovered their plant cover, indicating its rehabilitation (Majer, 1983; Majer et al., 1984; Andersen, 1993; Majer \& Nichols, 1998). In Brazil, similar results were found in areas of bauxite mines reforested with native and exotic species (Majer, 1992, 1996). 


\section{TABLE 1}

Ground-dwelling ant fauna in sites with high copper concentration (mine, solid, and liquid rejects), in a rehabilitation area, and at Parque das Guaritas (control site) in João Dias sub-basin, Caçapava do Sul, Camaquã Basin, RS, Brazil.

\begin{tabular}{|c|c|c|c|c|c|c|c|}
\hline Subfamily & Tribe & Species & Mine & $\begin{array}{l}\text { Solid } \\
\text { reject }\end{array}$ & $\begin{array}{l}\text { Liquid } \\
\text { reject }\end{array}$ & $\begin{array}{c}\text { Rehabi- } \\
\text { litation } \\
\text { area } \\
\end{array}$ & $\begin{array}{l}\text { P. das } \\
\text { Guaritas }\end{array}$ \\
\hline \multirow[t]{3}{*}{\begin{tabular}{|l} 
Dolichoderinae \\
\end{tabular}} & Tapinomini & Conomyrma sp.1 & $x$ & $x$ & $x$ & $x$ & $x$ \\
\hline & & Linepithema sp. & $x$ & - & - & $x$ & $x$ \\
\hline & & Tapinoma sp.2 & $x$ & - & - & - & $x$ \\
\hline \multirow[t]{12}{*}{ Formicinae } & Myrmelachistini & Brachymyrmex sp.1 & $x$ & $x$ & - & $x$ & $x$ \\
\hline & Camponotini & Camponotus rufipes & - & $x$ & $x$ & - & $x$ \\
\hline & & $\begin{array}{l}\text { C. (Myrmaphaenus) } \\
\text { fastigatus }\end{array}$ & $x$ & $x$ & $x$ & $x$ & $x$ \\
\hline & & Camponotus sp.1 & $x$ & $x$ & - & $x$ & $x$ \\
\hline & & Camponotus sp.2 & - & - & - & - & $x$ \\
\hline & & Camponotus sp.6 & - & - & - & $x$ & - \\
\hline & & Camponotus sp. 8 & $x$ & $x$ & - & $x$ & $x$ \\
\hline & & Camponotus sp.10 & - & $x$ & - & $x$ & $x$ \\
\hline & & Camponotus sp.11 & - & - & - & - & $x$ \\
\hline & Prenolepidini & Paratrechina sp. & - & - & $x$ & $x$ & $x$ \\
\hline & & Paratrechina sp.1 & - & $x$ & - & - & $x$ \\
\hline & & Paratrechina $\mathrm{sp} .2$ & - & $x$ & $x$ & - & $x$ \\
\hline \multirow[t]{15}{*}{ Myrmicinae } & Attini & $\begin{array}{l}\text { Acromyrmex } \\
\text { ambiguous }\end{array}$ & - & - & $x$ & - & $x$ \\
\hline & & $\begin{array}{l}\text { Acromyrmex } \\
\text { balzani }\end{array}$ & - & - & - & - & $x$ \\
\hline & & $\begin{array}{l}\text { Acromyrmex } \\
\text { crassispinus }\end{array}$ & - & - & $x$ & $x$ & - \\
\hline & & Acromyrmex heyeri & $x$ & - & $x$ & $x$ & $x$ \\
\hline & & $\begin{array}{l}\text { Acromyrmex } \\
\text { lobicornis }\end{array}$ & - & - & - & - & $x$ \\
\hline & & Acromyrmex lundi & $x$ & $x$ & $x$ & $x$ & $x$ \\
\hline & & $\begin{array}{l}\text { Acromyrmex } \\
\text { striatus }\end{array}$ & - & - & - & - & $x$ \\
\hline & & Acromyrmex sp. & - & - & - & - & $x$ \\
\hline & & Cyphomyrmex sp. & - & - & $x$ & - & $x$ \\
\hline & & Trachymyrmex sp. & - & - & - & - & $x$ \\
\hline & Crematogastrini & Crematogaster sp. & - & - & - & - & $x$ \\
\hline & & Crematogaster sp. 3 & - & $x$ & $x$ & $x$ & $x$ \\
\hline & Myrmicini & Hylomyrma sp. & - & - & - & - & $x$ \\
\hline & & Hylomyrma sp. 1 & $x$ & - & - & - & $x$ \\
\hline & & $\begin{array}{l}\text { Pogonomyrmex } \\
\text { cunicularius }\end{array}$ & - & - & - & $x$ & $x$ \\
\hline
\end{tabular}


TABLE 1 (Continued.)

\begin{tabular}{|c|c|c|c|c|c|c|c|}
\hline Subfamily & Tribe & Species & Mine & $\begin{array}{l}\text { Solid } \\
\text { reject }\end{array}$ & $\begin{array}{c}\text { Liquid } \\
\text { reject }\end{array}$ & $\begin{array}{l}\text { Rehabi- } \\
\text { litation } \\
\text { area }\end{array}$ & $\begin{array}{c}\text { P. das } \\
\text { Guaritas }\end{array}$ \\
\hline & Pheidolini & Pheidole fallax & - & $x$ & $x$ & $x$ & $x$ \\
\hline & & Pheidole sp.2 & $x$ & - & - & - & $x$ \\
\hline & & Pheidole sp.3 & $x$ & $x$ & - & - & $x$ \\
\hline & & Pheidole sp.5 & - & - & - & $x$ & $x$ \\
\hline & & Pheidole sp.6 & - & - & - & $x$ & $x$ \\
\hline & & Pheidole sp.8 & - & - & $x$ & - & - \\
\hline & & Pheidole sp.11 & - & - & - & - & $x$ \\
\hline & & Pheidole sp.12 & - & - & - & $x$ & - \\
\hline & & Pheidole sp.13 & - & - & - & - & $x$ \\
\hline & & Pheidole sp.15 & - & - & - & $x$ & $x$ \\
\hline & Ochetomyrmicini* & Wasmannia sp. & - & $x$ & - & $x$ & $x$ \\
\hline & & Wasmannia sp.1 & - & - & - & - & $x$ \\
\hline & Solenopsidini & Solenopsis invicta & $x$ & $x$ & $x$ & $x$ & $x$ \\
\hline & & $\begin{array}{l}\text { Solenopsis } \\
\text { (Diplorhoptrum) } \\
\text { sp. }\end{array}$ & - & - & - & - & $x$ \\
\hline & & Solenopsis sp.2 & - & - & - & - & $x$ \\
\hline & & Solenopsis sp. 3 & $x$ & - & - & - & $x$ \\
\hline & & Solenopsis sp.4 & - & $x$ & $x$ & - & $X$ \\
\hline \multirow[t]{2}{*}{ Ponerinae } & Ponerini & Pachycondyla sp. & - & - & - & $x$ & $x$ \\
\hline & & Pachycondyla sp.1 & - & - & - & - & $\mathrm{X}$ \\
\hline \multirow[t]{2}{*}{ Pseudomyrmecinae } & Pseudomyrmecini & $\begin{array}{l}\text { Pseudomyrmex } \\
\text { acanthobius }\end{array}$ & - & - & - & $x$ & - \\
\hline & & Pseudomyrmex sp.4 & - & - & - & $\mathrm{X}$ & - \\
\hline 5 & 12 & 51 & 14 & 16 & 15 & 24 & 45 \\
\hline
\end{tabular}

*Tribe according to Kempf (1972).

TABLE 2

Number of ant species of the three most frequent genera in sites with high copper concentrations (mine, solid, and liquid rejects), the rehabilitation site, and at Parque das Guaritas (control site) in João Dias sub-basin, Caçapava do Sul, Camaquã Basin, RS, Brazil.

\begin{tabular}{|l|l|c|c|c|c|c|c|}
\hline \multicolumn{1}{|c|}{ Subfamily } & \multicolumn{1}{|c|}{ Genus } & Mine & $\begin{array}{c}\text { Solid } \\
\text { reject }\end{array}$ & $\begin{array}{c}\text { Liquid } \\
\text { reject }\end{array}$ & $\begin{array}{c}\text { Rehabilitation } \\
\text { area }\end{array}$ & $\begin{array}{c}\text { P. das } \\
\text { Guaritas }\end{array}$ & $\begin{array}{c}\text { Total of } \\
\text { species }\end{array}$ \\
\hline Formicinae & Camponotus & 3 & 4 & 2 & 5 & 7 & 7 \\
\hline Myrmicinae & Acromyrmex & 2 & 1 & 4 & 3 & 7 & 8 \\
\hline & Pheidole & 2 & 2 & 2 & 5 & 8 & 9 \\
\hline
\end{tabular}


TABLE 3

Plant cover and the community structure of epigaeic ants in sites with high copper concentrations (mine, solid and liquid rejects), the rehabilitation site, and at Parque das Guaritas (control site) in João Dias sub-basin, Caçapava do Sul, Camaquã Basin, RS, Brazil.

\begin{tabular}{|l|c|c|c|c|c|}
\hline & Mine & Solid reject & Liquid reject & $\begin{array}{c}\text { Rehabilitation } \\
\text { area }\end{array}$ & $\begin{array}{c}\text { P. das } \\
\text { Guaritas }\end{array}$ \\
\hline Plant cover & None & Rare, sparse & Poor & Pinus & Rich, dense \\
\hline Richness of ant species (r) & 14 & 16 & 15 & 24 & 45 \\
\hline Exclusive ant species & 0 & 0 & 2 & 4 & 20 \\
\hline Shannon diversity (H) & 0.725 & 0.941 & 0.665 & 1.046 & 1.214 \\
\hline Sorensen similarity & & & & & \\
\hline Mine & - & - & - & - & - \\
\hline Solid reject & 0.400 & - & - & - & - \\
\hline Liquid reject & 0.308 & 0.476 & - & - & - \\
\hline Rehabilitation area & 0.095 & 0.345 & 0.182 & - & - \\
\hline Parque das Guaritas & 0.286 & 0.651 & 0.278 & 0.455 & - \\
\hline
\end{tabular}

Four out of 51 ant species from the João Dias sub-basin appeared in all five surveyed sites, explaining the low similarity among communities (Table 3). The ants communities of Parque das Guaritas and the solid reject site presented the greatest similarity $(0.651)$, while the lowest similarity (0.095) was found between the rehabilitation site and the mine itself.

According to Alonso \& Agosti (2000), data about species richness and composition of ants provide the baseline needed for employing these insects to monitor environmental changes, whether destructive or in rehabilitation. Many ant species have special requirements and their presence or absence in an area can be used as indicators of habitat change or restoration success. Activities in the copper mines caused enormous disturbances in the soil profile and in the composition of flora and fauna. For the affected areas, plans for their rehabilitation should be proposed. Local rehabilitation could be monitored through evaluation of the ground-dwelling ant fauna, which has also been used in Australia (Andersen, 1990, 1993; Majer \& Nichols, 1998). Recovery, observed from the data from the Camaquã Basin of the site used as a deposit for copper solid rejects and where later on, P. elliotti was planted, can be recognized by the increase in richness and diversity of the ant species present.

Acknowledgments - We wish to thank Maria Emília de P. Lucchese for help in the field; to Dr. Jacques Delabie of Laboratório de Mirmecologia, CEPEC/CEPLAC, who identified some ant species; and for the Scientific Initiation Grant from FAPERGS to C. E. D. Sanhudo, and from CNPq to Ed. Diehl-Fleig. We are grateful to FINEP and UNISINOS for their financial support.

\section{REFERENCES}

ALONSO, L. E. \& AGOSTI, D., 2000, Biodiversity studies, monitoring, and ants: an overview. In: D. Agosti, J. D. Majer, L. E. Alonso \& T. R. Schultz. Ants: Standard methods for measuring and monitoring biodiversity. Smithsonian Institution Press, Washington, pp. 1-8.

ANDERSEN, A. N., 1990, The use of ant communities to evaluate change in Australian terrestrial ecosystems: a review and a recipe. Proceedings of the Ecological Society of Australia, 16: 347-357.

ANDERSEN, A. N., 1993, Ants as indicators of restoration success at a uranium mine in tropical Australia. Restoration Ecology, 1: 156-167.

ANDERSEN, A. N., 2000, A global ecology of rainforest ants: functional groups in relation to environmental stress and disturbance. In: D. Agosti, J. D. Majer, L. E. Alonso \& T. R. Schultz. Ants: Standard methods for measuring and monitoring biodiversity. Smithsonian Institution Press, Washington, pp. 25-34. 
ESTEVES, F. de A., 1988, Fundamentos de Limnologia. Interciência/FINEP, 1575p.

GUADAGNIN, D. L., LAROCCA, J. \& SOBRAL, M., 2000, Flora vascular de interesse para a conservação da bacia do arroio João Dias: avaliação ecológica rápida. In: L. H. Ronchi \& A. O. C. Lobato. Minas do Camaquã, um estudo multidisciplinar. UNISINOS, pp. 71-84.

HANSEN, M. A. F. \& FENSTERSEIFER, H. C., 2000, Caracterização edafopedológica da sub-bacia do arroio João Dias como ferramenta de planejamento ambiental, Bacia Hidrográfica do Rio Camaquã, RS, Brasil. In: L. H. Ronchi \& A. O. C. Lobato. Minas do Camaquã, um estudo multidisciplinar. UNISINOS, pp. 211-240.

HÖLLDOBLER, B. \& WILSON, E. O., 1990, The ants. The Belknap Press of Harvard University, Cambridge, Mass, 732p.

KASPARI, M., 2000, A primer on ant ecology. In: D. Agosti, J. D. Majer, L. E. Alonso \& T. R. Schultz . Ants: standard methods for measuring and monitoring biodiversity. Smithsonian Institution Press, Washington, pp. 9-24..

KEMPF, W. W., 1972, Catálogo abreviado das formigas da região neotropical (Hymenoptera: Formicidae). Studia Entomologica, 15(1-4): 3-344.

MAJER, J. D., 1983, Ants: bio-indicators of minesite rehabilitation, land-use and land conservation. Environmental Management, 7: 375-383.

MAJER, J. D., DAY, J. E., KABAY, E. D. \& PERRIMAN, W. S., 1984, Recolonization by ants in bauxite mines rehabilitated by a number of different methods. Journal of Applied Ecology, 21: 355-375.

MAJER, J. C. \& KOCH, A. E., 1992, Ant recolonization of sand mines near Richards Bay, South Africa: an evaluation of progress with rehabilitation. South African Journal of Science, 88: 31-36.
MAJER, J. C. \& NICHOLS, O. G., 1998, Long-term recolinization patterns of ants in Western Australia rehabilitated bauxite mines with reference to their use as indicators of restoration success. Journal of Applied Ecology, 35: 161-182.

MAJER, J. D., 1992, Ant recolonization of rehabilited bauxite mines of Poços de Caldas, Brazil. Journal of Tropical Ecology, 8: 97-108.

MAJER, J. D., 1996, Ant recolonization of rehabilited bauxite mines at Trombetas, Pará, Brazil. Journal of Tropical Ecology, 12: 257-273.

MAYHÉ-NUNES, A. J. \& DIEHL-FLEIG, E., 1994, Distribuição do gênero Acromyrmex no Rio Grande do Sul. Acta Biologica Leopoldensia, 16: 115-118.

RICKLEFS, R. E. \& SCHLUTER, D., 1993, Species diversity in ecological communities: historical and geographical perspectives. The University of Chicago Press, London, 416p.

RONCHI, L. H., BAECKER, C. A. \& MARTINS, J., 2000, Avaliação do estado da qualidade das águas e da contaminação dos sedimentos recentes do arroio João Dias após encerramento das atividades das minas do Camaquã, RS. In: L. H. Ronchi \& A. O. C. Lobato. Minas do Camaquã, um estudo multidisciplinar. UNISINOS, pp. 241259 ..

SILVA, R. R. da \& BRANDÃO, C. R. F., 1999, Formigas (Hymenoptera: Formicidae) como indicadores da qualidade ambiental e da biodiversidade de outros invertebrados terrestres. Biotemas, 12(2): 55-73.

WILSON, E. O., 1976, Which are the prevalent genera of ants? Studia Entomologica, 19: 187-200.

ZAR, J. H. \& BROWER, K. R., 1997, Quantan: quantitative analysis in ecology. Dubuque, Iowa. Programmed for the IBM PC and Compatibles using QBASIC/QuickBASIC (May 1997 Version). 